Canadian University Music Review

Canadian University Music Review

Revue de musique des universités canadiennes

\title{
Classification Systems, Social Hierarchies, and Gender: Examining Indian "Light-Classical" Music
}

\section{Robert Ollikkala}

Volume 19, numéro 2, 1999

Canadian Perspectives in Ethnomusicology

Perspectives canadiennes en ethnomusicologie

URI : https://id.erudit.org/iderudit/1014444ar

DOI : https://doi.org/10.7202/1014444ar

Aller au sommaire du numéro

Éditeur(s)

Canadian University Music Society / Société de musique des universités canadiennes

ISSN

0710-0353 (imprimé)

2291-2436 (numérique)

Découvrir la revue

Citer cet article

Ollikkala, R. (1999). Classification Systems, Social Hierarchies, and Gender: Examining Indian "Light-Classical" Music. Canadian University Music Review / Revue de musique des universités canadiennes, 19(2), 27-36.

https://doi.org/10.7202/1014444ar

\section{Résumé de l'article}

Classification systems are connected to a socio-cultural and musical canon. In her introduction to Musicology and Difference (1993), Ruth Solie made the point that classification systems in music involve, imply, and reinforce social hierarchies. What Solie had to say about the Western classification system applies equally well to India. This study supports the assumption, which I believe will hold true for other geographic regions, that there are universal implications to the term "classical," implications that include, but reach far beyond, the musical. Specific to the Indian situation, however, are the particular historic dynamics involved in the subsidiary category known as "light-classical" music.
All Rights Reserved (C Canadian University Music Society / Société de musique des universités canadiennes, 1999
Ce document est protégé par la loi sur le droit d'auteur. L'utilisation des services d'Érudit (y compris la reproduction) est assujettie à sa politique d'utilisation que vous pouvez consulter en ligne.

https://apropos.erudit.org/fr/usagers/politique-dutilisation/ 


\section{CLASSIFICATION SYSTEMS, SOCIAL HIERARCHIES, AND GENDER: EXAMINING INDIAN “LIGHT-CLASSICAL” MUSIC}

\section{Robert Ollikkala}

In her introduction to the collection of essays, Musicology and Difference, ${ }^{1}$ which largely deals with power relationships in the Western musicological canon, Ruth Solie makes the point that classification systems in music involve, imply, and reinforce social hierarchies. She, along with a number of distinguished contributing scholars, highlights the connections between established musical categories and socio-cultural distinctions, particularly, issues of gender, race, class, ethnicity, and nationalism. This paper examines the same concerns as they relate to the "classical" music system and the associated socio-economic context in north India. It specifically focuses on a commonly acknowledged sub-category of the "classical" model, which is uncritically accepted by virtually all academics, performers, and aficionados, known as "light-classical" music. The genres of the "light-classical" category, although much loved, are consistently assumed to be less demanding derivatives, traditionally sung by women of "dubious virtue," of a male, sacred, classical model. Inherent in this widely accepted classification, and the associated implications, are dynamics similar to those that Solie and her peers address. These, for the most part, remain invisible to the participants; therein lies much of their power.

Two other books published within a year of Solie's, Bohlman and Bergeron's Disciplining Music: Musicology and Its Canons ${ }^{2}$ and Citron's Gender and the Musical Canon, ${ }^{3}$ also demonstrate that classification systems form an integral component of a Western scholarly and musical canon that informs and guides mainstream scholarship. As such, these classification systems influence academic articles and books, dominate scholarly discussions and forums, and seem to largely guide, perhaps even control, the thought processes (and vision of realities and possibilities) of the majority of the best and most influential scholars. They help form a discourse that largely circumscribes what we know, and what is worth knowing. These classifications help delineate, to a large extent, where research will go in the future, what is worthy of attention (and hence, I assume, both funding and a "voice"), and, coinciden-

1 Ruth A. Solie, "Introduction: On 'Difference,"' in Musicology and Difference: Gender and Sexuality in Music Scholarship, ed. Ruth A. Solie (Berkeley: University of California Press, 1993).

2 Katherine Bergeron and Philip V. Bohlman, eds., Disciplining Music: Musicology and Its Canons (Chicago: University of Chicago Press, 1992).

3Marcia J. Citron, Gender and the Musical Canon (Cambridge: Cambridge University Press, 1993). 
tally, what is generally considered to be unworthy and/or forbidden knowledge. Much of the theoretical insight provided by the previously cited authorsBohlman and Bergeron, Citron, and Solie-concerning canonical formations in Western musicology, is equally relevant in the Indian context. ${ }^{4}$ But it is also interesting to note that, conversely, much of what I am going to say about Indian classical music, and the connected socio-cultural milieu, applies equally well to the Western classical canon.

The Hindustani (north Indian) $)^{5}$ musical canon, like its Western counterpart centred on classical music, is conceptualized somewhat as follows. Music is classified, by both scholars and native performers, as falling into four basic categories: (1) "classical"; (2) a derivative style known as "light classical"; (3) "folk/tribal"; and (4) "popular," which also includes film music. It is commonly acknowledged that the core tradition, the most prestigious, the most revered, and the most successfully publicized internationally, is the "classical." It is, in India, the musical arm of the so-called "Great Tradition." The term itself ("Great Tradition") was coined by Singer and Redfield in the $1950 \mathrm{~s},{ }^{6}$ and its implications were developed at length by Singer in a famous book, When $a$ Great Tradition Modernizes, that is now an essential component of the scholarly literature on South Asia. ${ }^{7}$ The Great Tradition model is now an established paradigm of South Asian scholarship. According to Robert Redfield and Milton Singer:

The most important cultural consequence of primary urbanization is the transformation of the Little Tradition into a Great Tradition. Embodied in "sacred books" or "classics," sanctified by a cult, expressed in monuments, sculpture, painting, and architecture, served by the other arts and sciences, the Great Tradition becomes the core culture of an indigenous civilization and a source, consciously examined, for defining its moral, legal, aesthetic, and other cultural norms. A Great Tradition describes a way of life and as such is a vehicle and standard for those who share it to identify with one another as members of a common civilization. In terms of social structure, a significant event is the appearance of literati, those who represent the Great Tradition. The new forms of thought that now appear and extend themselves include reflective and systematic thought; the definition of fixed idea systems (theo-

4Robert Ollikkala, “Concerning Begum Akhtar, 'Queen' of Ghazal” (Ph.D. diss., University of Illinois, 1997).

5 There are two related but distinct classical music traditions in India: the Hindustani (northern) and the Carnatic (southern). The differences largely generate from the fact that although India is predominantly a Hindu nation, nevertheless much of the country (and particularly the northern region) was ruled by Muslims for five centuries. The Muslim invaders came from the northwest and their influenced diminished as they fought their way further south into the subcontinent. Hence the northern region is largely characterized by a mix of Hindu and Muslim influences, while the southern area is more Hindu. Muslim and Hindu ideals concerning the role and value of music in society are strikingly different, and thus the musical manifestations in the two areas are similarly distinct in many ways.

6Robert Redfield and Milton Singer, "The Cultural Role of Cities," Economic Development and Culture Change 3 (October 1954-July 1955): 53-73; repr. in Human Nature and the Study of Society: The Papers of Robert Redfield, ed. Margaret Park Redfield (Chicago: University of Chicago Press, 1962), 326-50.

7Milton Singer, When a Great Tradition Modernizes (New York: Praeger, 1972). 
logies, legal codes); the development of esoteric or otherwise generally inaccessible intellectual products carried forward, now in part separate from the tradition of the folk; and the creation of intellectual and aesthetic forms that are both traditional and original ...8

Singer later expanded upon this theoretical base and discussed the role played by cultural performances (both sacred and secular) that symbolize primary characteristics and beliefs of such a tradition. These include theatre performances, as well as music and dance recitals. Among the cultural specialists ("performers") that he interviewed and discussed-priests, scholars, storytellers, and actors-he included musicians and dancers."

"Classical music" has been, like other components of that Great Tradition, supported intellectually by centuries of musical scholarship as well as philosophical and theoretical treatises, and financially by aristocratic and titled patronage, and, more recently, by the more privileged middle and upper classes. "Classical music" is abstract, intellectually and emotionally demanding, and often associated with spiritual values; it requires years of training to become an accomplished performer, or even a knowledgeable listener. And, at least until the middle part of the twentieth century, and even beyond to a large extent, it has been a male tradition, dominated by male teachers and by performers entertaining male aficionados.

To focus on the Hindu framework for the moment, we can note that, according to a famous, often-cited work dating from the second to the fifth century, the Nátya-Sástra, it was the God Brahma who breathed musical knowledge into the author/scholar Bharata. Music was presented as a sacred art, the fifth Veda. ${ }^{10}$ Throughout the history of Indian classical music, and, particularly since the eighteenth century, male master musicians (ustáds and gurus) have guided devoted disciples (ságirds and sisyas) ${ }^{11}$ into a life focussed on music, one based on riyáz-practice as an intense secular and spiritual discipline. Melodic improvisation, based on rágas, ${ }^{12}$ requires a demanding

8Redfield and Singer, "The Cultural Role of Cities," 339.

9See Singer, When a Great Tradition Modernizes, 55-74.

10 In the Hindu religion there are four ancient sacred texts that continue to form the foundation for modern faith; these texts are known as the Vedas. In the Nátya-Sástra (literally, "Treatise on Dramaturgy" - which included music and dance), the importance of music in Hindu culture and religious life was emphasized to the extent that music was described as a fifth Veda. This was the author's interpretation, and is not (in a literal sense) a commonly held view.

11 The traditional student/teacher relationship in India is represented by the terms ustád/ságird and guru/sisya. Ustád/ságird are Muslim terms that refer to the connection between a dedicated student and a professional teacher who is a master of music. Guru/sisya are the Hindu equivalents; they add, to the above implications, the inference of a spiritual guide and a devout follower. Although in practice these terms are often used interchangeably, they nevertheless do highlight the different attitudes toward the value and role of music in society that characterize and separate the two cultures.

12Rága is the foundation of Indian melodic structure and improvisation. In north India there are said to be more than 300 different rágas. They are characterized by: the selection of pitches available (five, six, or seven, although this may vary in the ascending and descending forms); notable and common ornaments or patterns; the importance of particular notes; and a prevailing mood. Several rágas may actually feature the same notes, but be distinguishable one from another by such ornaments, patterns, a hierarchy of note relationships, mood, etc. Traditionally each rága has been associated with a particular 
technique and knowledge; stringent rules delineate the bounds that allow each to remain distinct, hence "pure." Tálas, rhythmic cycles, are similarly demanding.

By the nineteenth century, throughout northern India, family lineages known as gharánás, particularly among Muslims, guided and controlled musical knowledge and style. Neuman ${ }^{13}$ has described gharánás as established lineages, with identifiable and distinguishing musical styles, that require a discrete bloodline that dates back at least three generations. Gharánás throughout the nineteenth and twentieth centuries have been a source of knowledge and a stamp of musical approval that is a requirement for professional success. Gharánás ustáds today may teach anyone (although they traditionally have focused on male lineage members) but it is common knowledge that the real secrets are usually saved for a favourite son or nephew.

In the context of this dominant discourse-one that focuses on rága, tála, riyáz, gharáná, guru/sisya, etc., and one that is shared by both Indian and Western musical scholars that work in South Asia-we may inquire: "Where are the women, and what is their place in the canon and the connected classification system?" As an aside, I here note that Solie ${ }^{14}$ and Citron ${ }^{15}$ have demonstrated that in the West, at least until the mid-twentieth century, established women's roles largely held women back from participating on an equal footing with men in the professional music world; thus, there have been relatively few "great" female composers or performers of Western high art music. Female composers and artists in the nineteenth century, when they were successful, flourished in more intimate gatherings-aristocratic salonswhere they dealt with small works (commonly described as "miniatures"). In northern India, on the other hand, there has been an established place for women professionals who were as well trained and knowledgeable as their male counterparts. They, however, were not the respected begams-wives, mothers, and daughters-but, rather, the báis, the women who followed an inherited professional role. They were an essential component of the social fabric, respected for their skills in the arts of singing and dancing, but, also looked down upon for the intimate relationships that commonly occurred, and were generally expected, between themselves and their male patrons. They often shared the same ustád/ságird, guru/sisya relationships as their male counterparts, but only as students. They followed their riyáz and their dedication to the art with equal devotion. But it was generally understood by the women, their teachers, and their patrons, that their role was to sing a sub-category, a derivative style of the "classical" norm; women sang "light-classical" music. Most scholars, performers, and aficionados assume that "light-classical" music is more sensual, less technically demanding, and less stringent in

deity, and was only to be performed at a certain time during the day. The latter restriction is applied less stringently today.

13Daniel Neuman, "Gháránas: The Rise of Musical Houses in Delhi and Neighbouring Cities," in Eight Urban Musical Cultures, ed. Bruno Nettl (Urbana: University of Illinois Press, 1978).

14 Solie, "Introduction: On 'Difference."”

15 Citron, Gender and the Musical Canon. 
rága and tála requirements than its "pure" classical counterpart. While classical texts are often sacred, "light-classical" texts commonly imply both sacred and sensual innuendoes. Lighter rágas adhere to less stringent rules, and they are frequently mixed; thus, in classical terms, the integrity of a rága is essential, the "light-classical" counterparts are made "impure." There are no femalebased gharánás, and no light-classical gharánás. Famous female singers are absorbed into male lineages.

Historically, the great "classical" vocal forms-dhrupad, dhamár and later khyál-developed in the centre of the powerful Mughal empire, Delhi, between the sixteenth and nineteenth centuries. "Light-classical" forms, on the other hand, sung by the only class of professional female singers of the era, báis, developed in the subsidiary court of Lucknow in the nineteenth century. The historical record presents an image of the Mughal rulers in Delhi as virile and responsible. The historical record, that is, colonial and post-colonial historywhich developed in coincidence with the Hindu revival that forms such an important component of the Great Tradition model-also presents a picture of the Lucknow rulers, particularly the last and most famous, Wajid Ali Shah, in whose courts the "light-classical" music genres developed and flourished, as self-indulgent, weak, and debauched leaders. ${ }^{16}$

In sum, according to conventional understanding, everything about the "light-classical" category is lesser. This music is said to have been patronized by a group of ineffectual and self-indulgent rulers in a subsidiary court. It was sung by women of questionable moral character. With reference to "classical" ideals, texts are overly sensual, the forms are impoverished, the music is emotionally overcharged yet technically less demanding, less stringent, in rága and tála, etc.

I have, during the past few years, become increasingly uncomfortable with this overall characterization of North Indian "light-classical" music. Is this dominant discourse unassailable? What might have been overlooked? What assumptions warrant examination? We might inquire, for example: Is "light-classical" music really easier? Many of my informants, including the "light-classical" specialists Naina Devi ${ }^{17}$ and Shanti Hiranand, ${ }^{18}$ and the classical ustád Hafeez Ahmad Khan, ${ }^{19}$ disagree. They indicate that thorough classical knowledge and technique are crucial, but that these are then directed toward another goal, that of portraying emotional expression and various interpretations of repeated text segments. Rága blending is consciously carried out to serve this purpose.

Are emotions really less important than technical expertise, intellectual comprehension, and mastery of rága and tála? Well, not for many Indian aficionados. This seems to actually be a matter of taste. Many well-trained

16See, for example, Ollikkala, “Concerning Begum Akhtar, 'Queen' of Ghazal," particularly the transcripts of interviews with Shamsur Rahman Faroogi.

17Naina Devi, interviews by the author, 1990-91, New Delhi.

18Shanti Hiranand, interviews by the author, 1990-91, New Delhi.

19Hafeez Ahmad Khan, interviews by the author, 1991, New Delhi. 
listeners expect different things from different genres, and sensuality is a trademark of "light-classical music." But, because of the inherent connotations and currently undesirable historical references, emotionally charged, sensual performances of these genres are often seen as beautiful, yet problematic. The abstract classical purity has been tainted by earthbound sensuality and the current moral dilemma of the historical context.

Was Wajid Ali really as debauched and irresponsible as many historians lead us to believe? A few scholars, for example, Thomas Metcalf, ${ }^{20}$ have made the case that the British intentionally helped to create the weakened political and military condition which they then used as an excuse for deposing him. They believe that, without political and military might, Wajid Ali and his contemporaries were left with little else to do but entertain themselves and support the arts and artists in their care. The British were eager to get rid of Wajid Ali and his court, perhaps the last primary extant symbols of Mughal authority (which the British displaced as they entrenched the "raj," i.e., British rule in India). Veena Oldenburg indicates that Lord Dalhousie, the Governor General of India between 1848 and 1852, saw Lucknow (Oude) as a ripe "cherry" ready for imperial harvest. He wrote:

The King of Oude seems disposed to be bumptious. I wish he would be. To swallow him before I go would give me satisfaction. [He is a] cherry that will drop into our mouth one day, [especially if the British continue] shaking the tree to help it down. ${ }^{21}$

Is it sufficient to say that the reason why women were denied gharáná status is that there were no female or "light-classical" gharánás? This circular argument hardly seems appropriate.

Can the women specialists, the báis, really be criticized for following an inherited role, one designed to entertain men in a male-dominated social structure? That hardly seems fair. Báis, until independence, formed an important component of an established social structure. They were, until the midtwentieth century, the only group of professional artistic women, and the only women given a place in the social and public realm dominated by men. (Begams, by contrast, were confined by pard $a^{22}$ restrictions to a domestic role.) Báis were expected to entertain their male patrons with song, dance, poetry, and witty conversation. It was common (actually expected) for them to have an intimate relationship with a primary patron. Indeed, most men of means supported at least one bái, and this was viewed as a status symbol. Most upper-class males led two lives, spending the early part of the evening with their respectable parda wives and families, and the latter part with the báis.

20Thomas R. Metcalf, Land, Landlords and the British Raj (Berkeley: University of California Press, 1979), 39-40.

21 Cited in Veena Talwar Oldenburg, The Making of Colonial Lucknow (Delhi: Oxford University Press, 1984), 9.

22 Parda refers to the separation of women, in Islamic society, from the male, public realm. 
Is it reasonable to criticize high-class artists according to retrospectively imposed Victorian moral standards? One may counter that one of the most important effects of the colonial legacy, for women, was that British middleclass Victorian moral standards were adopted by the newly empowered Hindu (but British-trained) middle class which gained power after political independence. Neither these new rulers, nor their European colonial overlords, sympathized with the previously Muslim-dominated court social structure that supported the baiis, nor were the new rulers adequately trained to appreciate their art. And, it served both groups' political ends not to understand. The British, for their part, from the eighteenth century onward, wished to displace Muslim rule and entrench the raj. On the other hand, independence brought the new Hindu intelligenstia and administrative class the opportunity not only to take power from the British, but also to displace the Muslims who had ruled India for five centuries prior to the British. ${ }^{23}$ Thus, the establishment of Indian nationhood also introduced a resurgence of Hindu values that is commonly known, in the artistic realm, as the "Hindu Revival."

In a purely linguistic frame of reference, we can also note that the English term, "courtesan," commonly accepted as the equivalent of bái, is merely the closest available cross-cultural reference, but hardly a synonym. It carries extensive, and inaccurate, negative implications. The definition of "courtesan" in both the Oxford ${ }^{24}$ and Webster ${ }^{25}$ dictionaries connects the arts and artists with prostitution. High-class báis led an extravagant and liberal lifestyle, but the "courtesan" equivalent is too facile to be accurate, especially in the case of a great artist such as Begum Akhtar. ${ }^{26}$

Were the arts after independence-particularly "light-classical" music and kathak dance-really "rescued" (as is commonly stated and believed) from the báis by the reformers, Bhatkhande and Paluskar? ${ }^{27}$ I quote here from a book by Sobhana Nayar that presents a commonly held view of the impropriety of this professional class of women, and the hero/saviour status ascribed to the aforementioned scholars:

23A series of Muslim invasions from the Middle East, beginning in the seventh century, led to the establishment of Muslim rule throughout predominantly Hindu northern India from the thirteenth to the nineteenth centuries, at which time the British raj displaced the Muslims from the power centre. When India won independence from Britain in 1947 it was largely British-trained Hindus who dominated the political arena. In the political realm this power shift was perhaps most clearly manifest, and facilitated, by the bloody separation of the Muslim-dominated western part of the subcontinent into the separate nation Pakistan within a few months after India gained independence; the Muslim population in India was reduced from circa $30 \%$ in 1947 to about $11 \%$ in 1990. See Peter Manuel, Cassette Culture: Popular Music and Technology in North India (Chicago: University of Chicago Press, 1993), 93.

24The Oxford English Dictionary, 2d ed. (Oxford: Clarendon Press, 1989), 3:1061.

25 Webster Third New International Dictionary of the English Language (Springfield, Mass.: Merriam-Webster, 1986), 523.

26Ollikkala, "Concerning Begum Akhtar, 'Queen' of Ghazal," 1-171.

27Vishnu Narayan Bhatkande (1860-1936) and Vishnu Dagambar Paluskar (1872-1931) were highly revered performers and music scholars. They established a number of music conservatories through which middle-class, "respectable" boys and girls, in large numbers, could be trained to participate in the preservation and development of India's traditional arts. 
One man of Destiny to whom the highest credit goes for rescuing Indian Classical music from decadence, decline and extinction is Vishnu Narayan Bhatkhande. At a great personal sacrifice and suffering, and inspired by only one aim, Bhatkhande throughout his life undertook the herculean task of reviving Indian Classical music.

In the last few decades of the nineteenth century Bhatkhande found that the Indian Classical music, although it had a glorious history, had reached the bottom of degeneration and was looked down upon as unworthy, superfluous and vulgar-a subject fit for loafers and vagabonds. Bhatkhande radically altered the scene and put music once again on its high pedestal. ${ }^{28}$

Dr. Charles Fabri, in a text entitled Dance in India, shows a similar critical attitude:

This is a story of rescue done with complete consciousness, an almost missionary saving of an art that became a subject of contumely, a disgraceful practice despised by all. ${ }^{29}$

Of course, what is ignored in such statements is the fact that these female singers and dancers carried and developed "light-classical" music and kathak dance for two centuries. Many ustáds loved to sing these genres in private, but few would do so in public; such an action would have been viewed as a step down from their status as classical khyál specialists. One should also note that it is commonly known that the highly praised conservatories established by Paluskar and Bhatkhande, while providing a good training ground for knowledgeable listeners, cannot replace the guru-sisya tradition as a requirement for performance excellence; primary artists today still do not come out of the music conservatories. Nor, one might add, can they replace the koth $a^{30}$ atmosphere where the báis trained. Hence thumrí, a primary "light-classical" form, according to the "light-classical" specialists, Shanti Hiranand ${ }^{31}$ and Naina Devi, ${ }^{32}$ is dying along with the last remnants of the court culture. The other primary "light-classical" form, ghazal, is, in its most dominant current manifestation, a primary component of mainstream Indian pop and film music.

So, in summary, what am I saying? Am I condemning most previous Indian scholarship as being inadequate? No, not in the least! Am I condemning the world view of Indian performers as being narrow-minded? No again! We are all part of a time and place, and we are informed by that. What I am saying, however, is that I believe that it is productive, even important, to read against the grain, to question the assumptions and natural flow of the history-making process, of which we are also a part. To adopt the words of Michel Foucault,

28Sobhana Nayar, Bhatkhande's Contribution to Music (Bombay: Popular Prakashan, 1989), book jacket.

29 Charles Fabri, "Dance in India," The Indo-Asian Culture 10, no. 1 (1961): 70.

30 While the elite bais entertained in the courts and country estates of the titled very wealthy, most others worked in separate houses, kothás, which were established for that purpose.

31 Shanti Hiranand, interviews by the author, 1990-91, New Delhi.

32Naina Devi, interviews by the author, 1990-91, New Delhi. 
a "discursive formation" 33 has settled on South Asian music scholarship during this century, which involves a coherent system of musical work, academic writing, moral views, an interpretation of the historical and socio-cultural setting, a dominant religious perspective, etc., that are mutually self-affirming. I believe that Singer's magnificent text, When a Great Tradition Modernizes, along with the entire Great Tradition model, the connected "Hindu revival" and assumed "rescuing" of the arts from the hands of the báis, the entrenchment of colonial Victorian morality among the Indian middle class (and concurrently, I might add, the British middle class), as well as the hegemonically loaded term "light-classical" which is so widely used and uncritically unchallenged, and the place of that "light-classical" music (and the women who specialized in the style) in the classification system as important but derivative hence lesser-I believe that these are all part of a dominant discourse (in Foucault's words, a "discursive formation") that needs to be reexamined in the interest of critical scholarship.

Classification systems are not innocent. Classical norms in the musical realm and the connected socio-cultural realm involve hierarchy. There is something significant in the "light" part of "light-classical" that conveys a subtle message - or perhaps not so subtle when you examine it. "Light" consistently seems to imply "lesser," "derivative," "secondary," and "feminine." It is no coincidence that "light-classical" music, sung by women of assumed dubious virtue (within a role that they inherited in a male-dominated social structure) is considered to be more emotional (hence less valued in a male-dominated rational world), less technically demanding, less pure in terms of tála and rága. It is no coincidence that the texts for ghazals, sung by báis, yet written by males, are texts that deal with the plight of men injured by unfaithful lovers, and that these poems involve both sensual and sacred innuendoes. It is not by chance that the genres developed in the subsidiary court, Lucknow. It is not by chance that the Hindu revival, and later the Great Tradition model, came to be in the late colonial and post-colonial eras when middle-class Hindus assumed power from the British colonial rulers, and in so doing established an independent nation that was closer-in political organization and sensibility and middle-class Victorian moral ideals-to that of their British overlords than that of the Mughal rulers who had dominated the region for five centuries prior to the British. This homology of assumed historical

33Michel Foucault, in much of his writing, deals with all-encompassing predominant modes of thought and behaviour-"discursive formations"-that are foregrounded in a particular society at a certain period in history. "Discourse" in this context is not just speech and writing; all means of communication are components of the "discourse" of any period or region. Material objects, styles of architecture, moral concepts, manners of dress, games and sports, attitudes regarding appropriate male and female roles, and musical genres and styles-these are all elements within a consistent pattern, a "discursive formation." Foucault also describes the way in which an entire cultural perspective and the manifestation thereof (the "discourse") may shift from time to time-the manner in which a way of viewing and organizing a society dominates for a period of time, and then gives way to other formations which may dominate in other eras. "Discursive formations" delineate the parameters of that which one is able (or unable) to imagine, discuss, observe, and name. See Michel Foucault, The Archeology of Knowledge, trans. A. M. Sheridan Smith (New York: Pantheon Books, 1972). 
truths, moral assessments, cultural models, and musical classifications with inherent characteristics, warrants assessment as a cultural construct, a discursive formation of a particular time, place, and socio-cultural dynamic.

Classification systems are connected to a socio-cultural and musical canon. What Solie has to say about the Western classification system applies equally well to India. This study supports the assumption, which I believe will hold true for other geographic regions, that there are universal implications to the term "classical," implications that include, but reach far beyond, the musical. Specific to the Indian situation, however, are the particular historic dynamics involved in the subsidiary category known as "light-classical" music.

\begin{abstract}
Classification systems are connected to a socio-cultural and musical canon. In her introduction to Musicology and Difference (1993), Ruth Solie made the point that classification systems in music involve, imply, and reinforce social hierarchies. What Solie had to say about the Western classification system applies equally well to India. This study supports the assumption, which I believe will hold true for other geographic regions, that there are universal implications to the term "classical," implications that include, but reach far beyond, the musical. Specific to the Indian situation, however, are the particular historic dynamics involved in the subsidiary category known as "light-classical" music.
\end{abstract}

